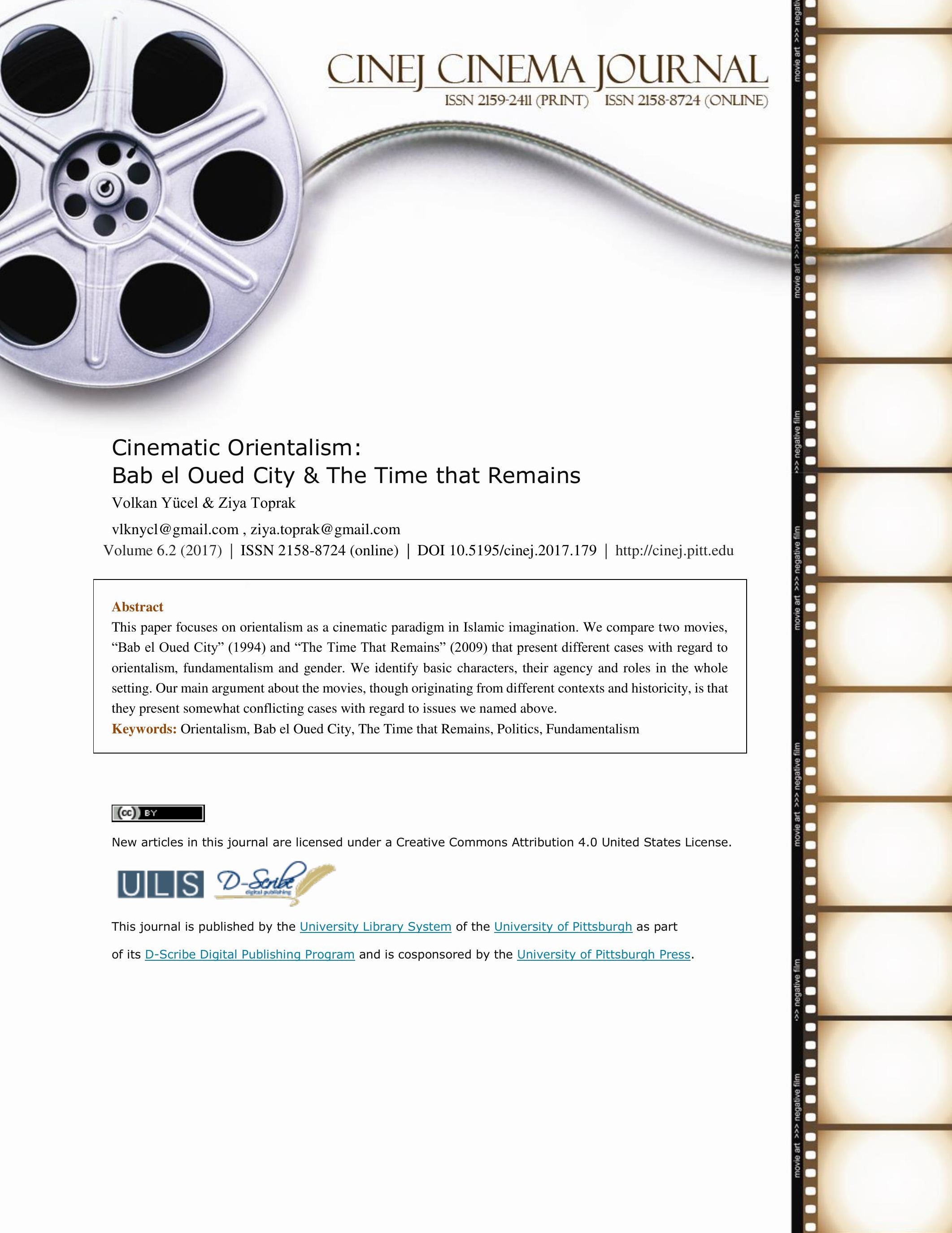




\section{Cinematic Orientalism: \\ Bab el Oued City \& The Time that Remains}

\section{Volkan Yücel \& Ziya Toprak}

\section{Introduction}

Cinema as such, provides unique spaces of documental materiality that present promises, aspirations, failed hopes, distorted affections, and narratives that bind micro and macro realms of making nations and imagined individuals. Bab el Oued City (Merzak Allouche, 1994), and The Time that Remains (Elia Suleiman, 2009), are among the Arab classics that exemplifies these unique, yet contradictory spaces that in the paper we dwell upon.

Bab el Oued City (Merzak Allouache, 1994) displays an intense case where fundamentalism, poverty, oppression, and a materialist culture intertwined. The movie successfully shows the failure of the revolution, the rising agenda of political Islam, and the gendered effects of post-revolutionary malaise. While doing these, the movie uses an orientalist way of depicting the daily life of Algeria, which soon will be shed with blood and harsh violence. On the other hand, The Time that Remains (Elia Suleiman, 2009) presents quite a different case. Its post-modern narrative, alienated environment, absurdity, sense of humor, questioning of existence, portrayal of violence in its banality, loss, and belonging are among the major things that we noticed while watching the film.

In this paper, we discuss these broader issues in the light of what the movies display. In doing this, first we provide the details of the setting, the context and the characters, which constitute a triangulated relationship that helps the viewer to sense what has happened, is happening and will happen. The second part of the paper will deal with the discourse of orientalism that the directors bring in and choose as a way of depicting the Eastern lives. Then we move on to the discussion of the fundamentalism. Our last concern is about gendered effects of these contexts 
and depiction of women in these landscapes. We will conclude our paper with a discussion of the overall failure of the revolution, the place of the film in this broader context and a postscript on the coming of the civil war. Our main argument about the movies, though originating from different contexts and historicity, is that they present somewhat conflicting cases with regarded similar issues.

\section{The Context}

\section{Bab el Oued City}

Even though the movie was shot in a postcolonial era, the broader context that the movie takes place has several overlapping contexts that merged into each other. There is the colonial context, the revolution context, October 88 context and the coming context of civil war. The movie is built upon all of these contexts where each is felt in different scenes and different characters.

The colonial context is omnipresent and very sensible throughout the movie, especially in the shots of colonial architecture; the Cathédrale Notre-Dame d'Afrique and gothic buildings. It is also characterized in the blind aunt and her nephew. The relationship built with the colonial context is somewhat problematic in the sense that it recalls the context nostalgically. Just as the colonial context, the revolution context is omnipresent though not nostalgically. There is a sense of dichotomy between the revolution and the colonial context where the former represents a failure, a loss and disappointment and the latter is referred as something to worthy of remembering nostalgically. In fact, the whole context of the movie builds on the sense of loss and disappointment created by the revolution. The sense of security, belonging is lost in this post-revolution quartier. This sense of loss is deepened, especially by the October 88 when the strikes in the country became endemic and in response, the government "... declared a state of siege and the repression began in earnest. In addition to billy clubs and tear gas, the security forces began using live fire and 
ultimately resorted several kinds if automatic weapons. Before the order was more or less restored on October 10 hundreds of Algerians-mostly young men- had died; and thousands had taken into custody where many were tortured.” (Ruedy, 2005, 248)

The movie is narrated aftermath of the events of October 88. However, apart from several overt referrals through the letters wrote to the main male character by the main female character, we are not informed about the events. In fact, the October 88 remains as a mystery. The setting of the movie shows what has left after the October 88; danger, fear and loss. The movie also gives indications of the coming the civil war that denotes a tragic state in the lives of Algerians. At some point, one can read the movie as the chronicle of events that will eventually yield to a civil war. From a loudspeaker to civil war, in essence the movie tells the beginning of the end in a microcosm of Algiers; Bab el Oued.

\section{The Time that Remains}

In its broader context, the movie presents the colonization of a formerly Palestinian city, Nazareth by the Israeli government. We witness that the Arab inhabitants of Nazareth got "third class" and were "... kept under martial law and police state controls.” (Khalidi, 2006, p. 191) Through this colonization, we see that war conditions normalized and the evil banalized. There were several scenes in which we could sense the normalized view of warlike conditions. One of them was in which Fuad was beaten and thrown away among the olive trees. It was as if the director was telling that to be beaten to death and olive trees were equally part of the daily life. We found the analogy striking. In another scene, a young adult was shown talking to someone on the phone about a party while the main gun of a tank literally following his steps. More interestingly, the young adult kept going to talk indifferently as if the tank was not there. These two scenes were 
especially striking in the sense that they implied a normalized view of warlike conditions and the banality of evil.

The movie also depicts the extent of how the lands of Palestinians have turned into an open prison in a panoptical sense through mechanisms of bureaucracy. There were plenty of scenes that showed the surveillance of inhabitants, such as bulgur-gun powder incident and regular spotting of Fuad and his friend while fishing by Israeli patrols.

\section{The Setting}

\section{Bab el Oued City}

The movie was shot in Bab el Oued, a geographically minor district in the capital city Algiers. During the colonial times, the neighborhood was occupied by pied-noirs. During the independence war, the district was held by Organisation de l'armée secrète (OAS). After the revolution and with pied noir population leaving the country, working class Muslim Algerians occupied the district. The district also played an important role in the civil war as a stronghold of Islamists.

One, who watches movies about the Middle East and Arab world, can easily notice that almost in all of them, cities or settings appear as an integrative character, which is also the case in Bab el Oued City. As popular working class quartier in the city of Algiers, Bab el Oued, is an oued (valley) where flows, erosions, destructions and remaking take place. Once a place of sanctuary for the young, the oued is torn apart culturally, politically and soon geographically:

"For Algerians, especially for young men, it was more of a sanctuary than the family home. It was a place where young people could create their own sense of family... So in this way, the quartier [Bab el Oued] and what it had represented played a very important role in the lives of young people in Algiers. But now everything has changed. There is great sense of mistrust between people. There is 
an endless cycle of violence which has become a daily realty." (Hadani, 1995, 34)

As noted by the director himself in the above quotation, the setting of the movie itself a represent a transformation and the characters try to find their ways by fabricating their own reality. The director profoundly uses this setting to create a claustrophobic atmosphere where soon terrible things will happen.

\section{The Time that Remains}

Unlike the presentation of space in Bab el Oued City, The Time that Remains, reminds us that there is hope regarding the space. The film was shot in a large city of North District of Israel, where population is consisted of predominantly Christian and Muslim Arabs. In this sense, the city constructs an interesting space where it is not possible to be a Muslim, Christian or even Israeli. The only possibility seems to be is, in Deleuzeian terms, becoming and flux. The space, the time, and the characters are not fixed in the movie, which we think is one of the main points that the director makes. They always change, and turn into different not beings but becomings.

Nazareth is a liminal space where there is the possibility of hope, transcultural dialogue, and deconstruction of existing power and inequality relations. "This space, awkward and difficult though it may be, still holds promise for peace, but it needs to be freed from preconceptions, assumptions and representations" (Mavroudi, 2013, 565). The setting of the movie is another character that invokes a space where there is the possibility of thought and reflection. Just as the "Rida Café," the space in this movie is dynamic and always in flux. In one scene, we see that the café is harboring young people with guns and in another; we see it as a space where old friends meet. 


\section{The Characters}

\section{Bab el Oued City}

Boualem: Boualem is the central male character and a baker who is young and resilient. He is an ordinary man who only wants a peaceful and quite life. He represents the working class man who has an open and a secular mind. Yet his life is haunted by historical forces like political Islam, which he acts against not that he is a non-believer. Since, he can take the infiltrations of religion through a loudspeaker into his private life no more. Therefore, he tears down the loudspeaker and throws into the sea and hence the narrative begins. It is meaningful to throw the speaker to the sea within the context of the movie where the sea represents the salvation and the way to Europe. In the end, Boualem opts out the narrative and goes to Europe by the sea.

Said: Said is the antagonist of Boualem and what he is. Said is the agent of political Islam and religious fundamentalism. He contradictorily wears a leather jacket, works out in the gym because he is also representing the physical bully. This despotic and brutal character in the context of the movie is the agency of the evil. In the end, we are informed that he is dead which is no surprise given the way he opts live.

Yamina: The sister of Said and the sweetheart of the Boualem. She represents the oppressed woman of Algeria. She is imprisoned by and oppressed by her brutal brother.

Ouardya: She is the character that Boualem occasionally visits and gets drinks for her. She is alone and rich. She is the most depressed character and feels the sense of loss deepest. She becomes a target for the religious gang. In the movie, she represents the loss of 'left sense' of the country. We can see this from the portrait of Che in her apartment and her own words: "When I was a student a long time ago, we believed in beautiful things; the revolution, helping the Third World, Marxism. We were mobilized as we used to say. Our life was devoted to the people. It was 
a new country and the student movement was strong. We were romantic and I was in love... We ended up in prison."

The Aunt and The Nephew: They are the former colonial dwellers of the neighborhood. Throughout the film, the nephew narrates the city to her blind aunt. He tells about how nothing has changed and how the city became beautiful. Soon, the aunt realizes that the city is longer the same. We witness the following dialogue:

The Nephew: "If you could see the view, Auntie. Just like it used to be. The buildings are so white, mixing with the blue sky. It is superb. If I were a painter, I would come here for inspiration."

The Aunt: "I smell such an odor."

The city is so dirty that it is not possible to fool even a blind person. They represent the nostalgia for the colonial Algeria, which is a very problematic point that the movie makes.

\section{The Time that Remains}

Fuad: He is the main character until he disappears. He is the father of the ES, i.e. the director. He is handsome and cool. In the beginning, he is a young rebellion who helps Arab militants by making and fixing guns. After the Israeli soldiers notice his efforts, he is beaten to death but somehow he survives. Later, we see him as the father and the head of the family who has responsibility and hobbies like fishing. Fuad represents the dynamicity of the film, his transition and becoming never ends. He is always becoming something, from rebellious to fathering, from a man with hobbies to helpful and caring adult. His character changes also transform the time and space of the movie. 
ES: He is the son of Fuad and the director of the film. In this sense, the film is semiautobiographical. He is the man who returns to his country where once he forced to leave. His return changes the time, the pace and space of the movie. Before he steps in, the time is more dynamic and events are more exciting. When he steps in, the time is slower with plenty of pauses both in time and in space. These pauses are very striking in the senses that they are very significant. They provide the space for thinking and reflection about the construction of power relations. His appearance also denotes a subtle and a more absurd turn in the movie. He is not the exotic wanderer in the city. He is a lost soul trying to find his roots that were already in a state of impossible to find. He is a present absentee.

\section{Orientalism}

The movie Bab El-Oued City is with full of representations, images of and aspirations about what it is thought to be 'the East', a source of self-orientalizing. The concept of orientalism is here understood in terms of Edward Said's (1979) "Orientalism" which has been very influential in post-colonial studies. The book mainly deals with the representations, imaginations and articulations of East in the works of Western writers. In this sense, the east is represented as primitive, chaotic, despotic, dangerous, violent, overpopulated, ignorant, exotic, insensitive, feminine and erotic. It is shocking that there are plenty of such representations in the movie.

However, there is a minor difference; the director is actually from Algeria. In this sense, the movie is self-orientalizing. In other words, the director looks to himself in the eye of a Westerner. In his interview, the director explicitly exemplifies this: "There is an endless cycle of violence which has become a daily realty. Therefore, the quartier is no longer a cocoon, which protects people, because there is now a great sense of fear and danger, as if anything could happen... There is no longer a sense of security." (Flores-Khalil, 2006) What the director describes 
is also reflected in the movie. The women are imprisoned, the sense of security is lost, the flats are overpopulated, the city is dirty and messed up, and the only thing that one can do in order to be free of oppression is to escape from the city as Boualem does in the end.

In his spectacular work (Black Skin, White Masks, 2008) Frantz Fanon deals with the self, psyche and the colonial condition. Elsewhere he notes that:

"If psychiatry is the medical technique that aims to enable man no longer to be a stranger to his environment, I owe it to myself to affirm that the Arab, permanently an alien in his own country, lives in a state of absolute depersonalization ... The social structure existing in Algeria was hostile to any attempt to put the individual back where he belonged." (Fanon, 1967, 53)

In essence, he says that those who experienced French colonialism were also psychologically transformed. The enslaved and blinded black accepts the norms of the white. S/he internalizes the values of the white without noticing it. In other words, the black looks him/herself within the eye of the white; i.e. self-orientalizes him/herself. This is our overall argument about the movie. The director, who lives in Paris, has produced an orientalist narrative of Bab el Oued, which is evident, especially from the characters of the aunt and the Nephew.

On the other hand, in most senses, The Time that Remains is what Bab el Oued is not and orientalism is one of these senses. Like the director of Bab el Oued City, Elia Suleiman is also a man returning to the land. This is the only similarity between two directors. While, Allouache constructs an orientalist space, Suleiman constructs a liminal space where private spaces turn into political public spaces. In fact, one could rightfully read this film as an act of resistance, which organized in a liminal space where the line between the private and public became blurred and fluid. This liminality also denotes the complicated sense of belonging of the director. He is in a liminal space between home and exile, and self and nation. The Time that Remains does not attempt 
to represent the orient or redefine it. In fact, the sense of the direction is lost in the movie. From the beginning, we see how the colonial force structures the space and maintains it as an open prison. Hence, we do not feel any sense of oriental but a colonial, lost and liminal space.

\section{Fundamentalism}

Within the Bab el Oued City, we see two versions of Islam; one is moderate and peaceful embodied in the imam character, who eventually yields and leaves, and the fundamentalist Islam embodied in Said and his gang, who eventually dominates and bloodies the city. We see the rise of fundamentalism, but we do not see why. Although there is not much context about how Islamism comes to dominate the politics of the country, in his interview, the director states, "After Algerian Independence, there was a trend of Arabization. As a result, many teachers were brought in from Egypt, to instruct children in classical Arabic. However, the majority of these teachers was Muslim brothers. This was how the new generation was formed." (Hadani, 1995, 36) As much as this explanation sounds plausible, it misses a major point. After 1980s, the global agenda was being influenced by neoliberalism, which was accompanied by neo-conservatism. This has been the case in other countries like Egypt, Lebanon, and Palestine. The case is very similar in Turkey as well. From the beginning of the 1980s, Turkey has been under the influence neoliberalism and political Islam.

On the other hand, the movie explains the rise of political Islam and fundamentalism with the absent father as a paternal figure. There is no father in the movie. The closest character to a paternal figure is the character Imam who defends the moderate Islam and peace. He constantly warns youngsters to stay away from violence, because "violence breeds violence". Yet eventually he opts out the narrative and leaves the stage to the extremists. This is a breaking point in the sense that, the moderate paternal figure leaves and the violence breeds. 
On the other hand, religion in The Time that Remains, unlike in Bab el Oued City, does not appear as a foundational element. It is just a theme that remains in the background. The story is not about the religion or the fundamentalism that it produces, it is about the loss, belonging and space where Christianity and Islam coexist. Suleiman emphasizes the value of this space "... as its in-between-ness stresses the need to unpack how identities, us/ them relationships and Othering are negotiated in material and symbolic ways." (Mavroudi, 2013, 565) In this sense, the movie does not problematize the identities and their features, but their relations to one another and how they could negotiate their differences and coexist. Unlike Bab el Oued City, there is the possibility of overcoming barriers by a pole in The Time that Remains, which also demonstrates the existence of hope.

\section{Gender}

The women, oppressed and abused by men, in Bab-el Oued City are mostly in the background in the film. Her extremist brother closes Yamina in her home. She cannot even to stand near the window freely. Her brother angrily warns her by saying "You are always in front of the windows. Soon, there will be a wall, you won't see the sun anymore." The general feeling that the viewer gets that women are trapped by brutal, despotic men is a striking feminist critique.

However, as we have just noted, the destruction of the county is explained by the absence of a paternal figure. In this sense, the movie has a problematic view of gender. On the other hand, we see women who are closed and imprisoned to roofs where they can have access to 'the outside' relatively freely. However, this should not be read as a feminist critique of patriarchy, but rather a secular critique of the rising agenda of political Islam. The main thing that the movie problematizes 
about the gender is the restriction of woman to access to streets, which is why we constantly see women looking down to streets from windows and roofs.

On the contrary, we found the film somewhat homophobic to an extent. In one scene, we see a group of women, being entertained by a 'seemingly gay' character on a roof. In this scene, the movie fails to produce a feminist critique. By folklorising the character, the movie implies that homosexuality is something that we can laugh at. In this sense, the movie is quite homophobic.

On the other hand, although The Time that Remains is not harsh as Bab el Oued City in the depiction of a woman, it also presents gendered look. We come to this conclusion by the absence of a proper female character. First, there is no central female character. We see the aunt as a teacher who almost lost his mind and the mother of ES. The mother is traditionally mother. She does not have any agency and her duties are mainly household duties like cooking, and cleaning. We even

do not know her destiny, what happened to her? She just disappears. On the other hand, we would like to be very cautious while discussing Suleiman's approach to gender because we know from his other movie, the "Divine Intervention" that he is very critical to gender issues. In that film, the Arab-Israeli conflict is also presented as a gender conflict. On the one side, there is masculine Israeli violence and on the other, the feminine resistance.

\section{Conclusion}

Bab el Oued City, in its simplest sense, is an orientalist look to Algeria's culture and past and a secular critique of the rising agenda of political Islam. By producing a certain antagonism, the movie tries to read the conditions that eventually yield to the civil war. We see the coming of the civil war and conditions that set the social background of the war. However, the movie produces significant problematics in doing this like self-orientalization, reproducing patriarchal relations, and homophobia. 
Nonetheless, the film is successful in transferring the feelings of yearning, nostalgia, fear, danger, and claustrophobia. The film manages to display a society on the threshold of moving into something disastrous. We can sense the transition of Islamists from street bullies to terrorists. Interestingly, we do not see the state and its role in this transition. The film successfully shows this transition, which would eventually yield to bombings, kidnappings, and assassination by Islamic fundamentalists, and government's brutal response. In the end, the civil war caused the loss of tens of thousands of lives, including, journalists, artists and intellectuals.

On the other hand, The Time that Remains represents a more successful case with regard to the issues that have been discussed. The movie is about the space, loss, belonging and becoming. Within this space, we see that the Israeli occupation is normalized and has become a part of daily life, a notion evident in Ramallah scenes. The film is a very funny, sentimental one combining surreal and absurd chain of events and using a poetic style. The film is about the director. In the article on Palestinian cinema, Alexander (2005) states "There is no real public space, either physically or psychologically, where broader groups socialize or interact. There is no story." It seems that his ideas are misleading. First, if there was no public space, we could not see any resistance which we see plenty in the film. Alexander seems missing the fact that private spaces have turned into public spaces where resistance is organized. In fact, one could rightfully read this film as an act of resistance, which organized in a liminal space where the line between the private and public became blurred and fluid. This liminality also denotes the complicated sense of belonging of the film. It is in a liminal space between home and exile, and self and nation. 


\section{BIBLIOGRAPHY}

Alexander, L. (2005). "Is there a Palestinian Cinema? The National and Transnational in Palestinian Film Production," in Palestine, Israel and the Politics of Popular Culture, pp. 150-72. Durham: Duke University Press.

Fanon, F. (1967). Toward the African Revolution. New York: Grove Press.

Fanon, F. (2008). Black Skins, White Masks. London: Pluto Press.

Flores-Khalil, A. (2006). "Interview with Merzak Allouache," The Journal of North African Studies, 10(2), pp. 143-156.

Hadani, D. (1995). "Torn Apart: Merzak Allouache on Algeria, fundamentalism, cinema and nostalgia," Sight \& Sound, 5(9), pp. 34-36.

Mavroudi, E. (2013). Creating geographies of hope through film: performing space in PalestineIsrael. Transaction of the Institute of British Geographers, pp. 560-571. DOI: 10.1111/j.14755661.2012.00546.x.

Rashid K. (2006). The Iron Cage: The Story of the Palestinian Struggle for Statehood. Boston: Beacon Press.

Ruedy, J. (2005). Modern Algeria: The Origins and Development of a Nation. Bloomington: Indiana University Press.

Said, E. (1979). Orientalism. New York: Vintage. 


\section{FIGURE LIST}

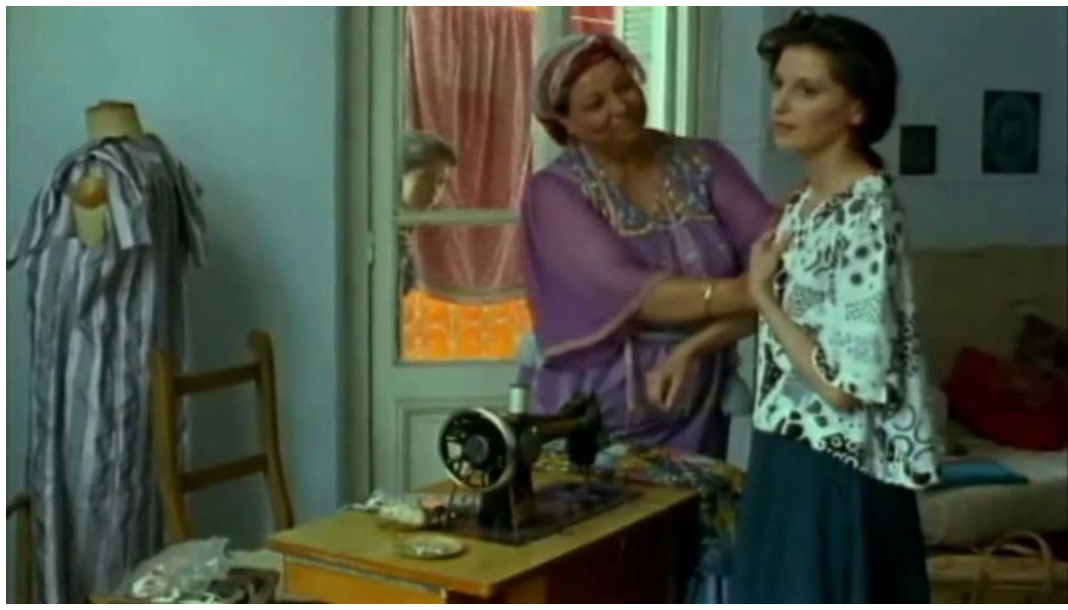

Figure 1 Bab el Oued City

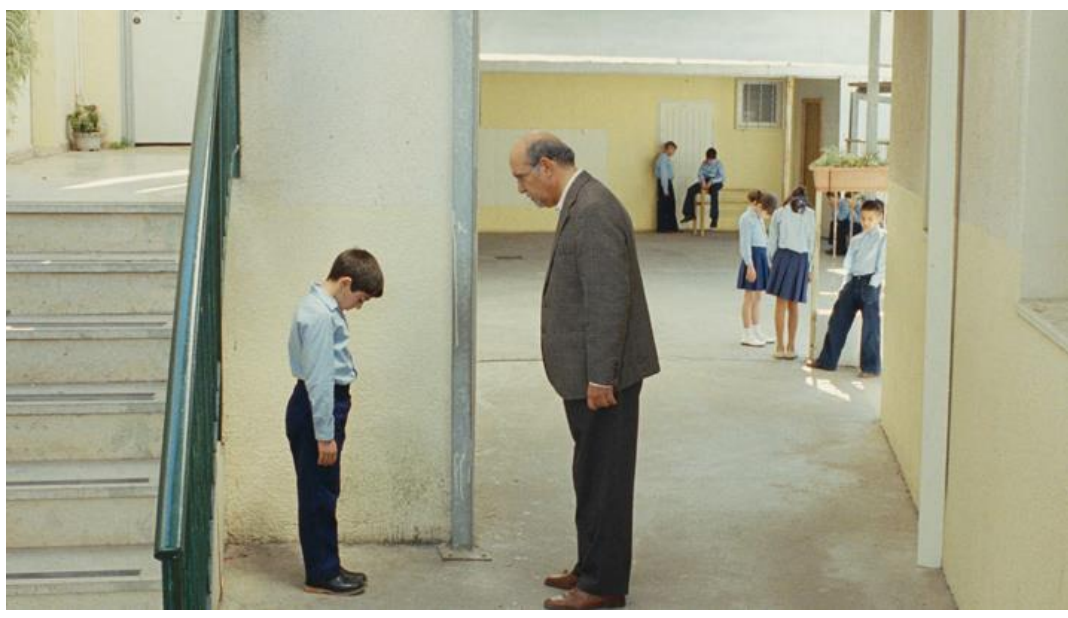

Figure 2 The Time that Remains 